\title{
Michel Brix, Hugo et Sainte-Beuve. Vie et mort d'une amitié «littéraire»
}

\section{Lise Sabourin}

\section{(2) OpenEdition}

10 Journals

\section{Édition électronique}

URL : http://journals.openedition.org/studifrancesi/9292

DOI : 10.4000/studifrancesi.9292

ISSN : 2421-5856

Éditeur

Rosenberg \& Sellier

\section{Édition imprimée}

Date de publication : 1 juin 2008

Pagination : 211

ISSN : 0039-2944

\section{Référence électronique}

Lise Sabourin, « Michel Brix, Hugo et Sainte-Beuve. Vie et mort d'une amitié «littéraire» », Studi Francesi [En ligne], 154 (LII | I) | 2008, mis en ligne le 30 novembre 2015, consulté le 13 janvier 2021. URL : http:// journals.openedition.org/studifrancesi/9292 ; DOI : https://doi.org/10.4000/studifrancesi.9292

Ce document a été généré automatiquement le 13 janvier 2021.

\section{(c) (i) (9)}

Studi Francesi è distribuita con Licenza Creative Commons Attribuzione - Non commerciale - Non opere derivate 4.0 Internazionale. 


\title{
Michel Brix, Hugo et Sainte-Beuve. Vie et mort d'une amitié «littéraire»
}

\author{
Lise Sabourin
}

\section{RÉFÉRENCE}

MICHEL BRIX, Hugo et Sainte-Beuve. Vie et mort d'une amitié «littéraire», [2 impasse des

Peintres 75002] Paris, Éditions Kimé, 2007, pp. 142.

1 Alors que l'opinion a pris l'habitude de déconsidérer la critique beuvienne - après Proust comme du vivant de celui qu'on surnommait Sainte Bévue ou Sainte Bave selon sa myopie sur les contemporains ou le venin de ses analyses-Michel Brix ose, aujourd'hui où l'on réévalue la place de sa méthode dans l'histoire littéraire, rouvrir le dossier du procès fait au critique, notamment dans ses rapports avec le grand Hugo. Son livre s'attache à dépasser les faits biographiques (dont, bien sûr, la brève liaison avec Adèle) habituellement considérés dans la rupture de leur amitié pour situer plutôt leur écart au niveau du contentieux littéraire lié à l'évolution de l'esthétique romantique et au statut accordé à la critique face au rôle de l'artiste.

2 M. Brix remarque que la divergence tient sans doute d'abord à l'éloge - parfois proche de l'adulation: «frère, il faut me louer» - que paraît requérir Hugo, alors que SainteBeuve revendique son droit à la distance critique, en une écriture de jugement dont le poids est attesté par la virulence même des réactions hugoliennes à ses appréciations. Ainsi, dans leurs discussions sur la poésie, à propos de l'attachement persistant de Sainte-Beuve à Chénier, ou sur les buts du roman, quand le critique considère davantage la dimension poétique qu'historique de Notre-Dame de Paris. Autre point d'achoppement: le critique a su discerner le lyrisme personnel hugolien, caché sous les intentions engagées du premier romantisme, dès sa jeunesse plus rhétorique et mystique. Les Poésies de Joseph Delorme témoignent de cette voie intime que SainteBeuve est enclin à voir comme essentielle au devenir du genre poétique. De même, il incite les romanciers à adopter une écriture plus réaliste que ne l'a demandée la 
substitution de la transcendance du premier romantisme à la théorie du beau idéal classique. Sainte-Beuve critique encore Hugo dans sa relation avec le public, qu'il lui semble dédaigner en y substituant un cénacle de thuriféraires; or le critique préfère envisager l'écrivain comme thérapeute par partage des souffrances éprouvées: il invite donc ses anciens amis à s'humaniser par proximité, à quitter leur vision d'une littérature prophétique. M. Brix remarque qu'après sa rupture avec Hugo, Sainte-Beuve s'intéresse surtout aux auteurs qui n'ont pas mis la gloire pour principe à leur carrière, aux femmes auteurs, jugées plus modestes et naturelles du fait de leur condition sociale, se donne finalement la mission de faire connaitre les humbles qui ne se sont pas mis eux-mêmes en lumière.

3 On lira avec intérêt ce petit livre discursif qui s'ouvre également à d'autres appréciations de Sainte-Beuve sur ses contemporains (Sand, Gautier, Baudelaire ou Balzac), tout en proposant une thèse roborative, qui va à l'encontre des idées reçues. 